\title{
Limb-Girdle Muscular Dystrophy Type 2B
}

National Cancer Institute

\section{Source}

National Cancer Institute. Limb-Girdle Muscular Dystrophy Type 2B. NCI Thesaurus.

Code C142080.

An autosomal recessive condition caused by mutation(s) in the DYSF gene, encoding dysferlin. It is characterized by progressive muscular dystrophy, primarily affecting the proximal muscles, resulting in difficulty walking. 